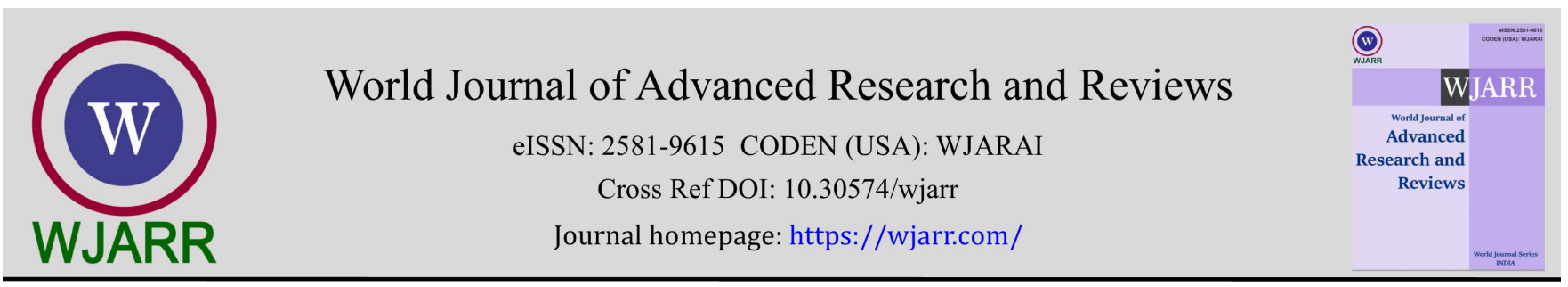

(RESEARCH ARTiClE)

\title{
Prevalence and genotypic characteristics of Panton-Valentine Leukocidin-producing Staphylococcus aureus isolates obtained in Jos, North Central Nigeria
}

\author{
Unyime C. Essien 1, 2, ${ }^{*}$, Samar S. Boswihi ${ }^{3}$, Nneka R. Agbakoba ${ }^{2}$ and Edet E. Udo ${ }^{3}$ \\ ${ }^{1}$ Department of Medical Laboratory Science, Faculty of Health Sciences and Technology, University of Jos, Nigeria. \\ 2 Department of Medical Laboratory Science, Nnamdi Azikiwe University, Nnewi Campus, Anambra State, Nigeria. \\ 3 Department of Microbiology, Faculty of Medicine, Kuwait University, Kuwait.
}

World Journal of Advanced Research and Reviews, 2021, 11(02), 263-275

Publication history: Received on 14 July 2021; revised on 18 August 2021; accepted on 20 August 2021

Article DOI: https://doi.org/10.30574/wjarr.2021.11.2.0387

\begin{abstract}
Abstract

Background: Staphylococcus aureus is an opportunistic pathogen that colonizes and causes infections in humans. Panton Valentine Leukocidin (PVL) is a cytolytic toxin produced by some strains of $S$. aureus and are mostly associated with skin and soft tissue infections and necrotizing pneumonia.
\end{abstract}

Aim: To investigate the prevalence and genotypic characteristics of PVL-positive $S$. aureus strains cultured from patients in three tertiary hospitals in Jos, Nigeria.

Methods: Two hundred and fourteen clinical $S$. aureus isolates were obtained from three tertiary hospitals in Jos. Polymerase chain reaction was used to detect lukSF-PV gene that encodes PVL, and sensitivity to antimicrobial agents was performed on PVL-positive S. aureus. Genotypic characteristics of the PVL-positive S. aureus was determined by spa typing and multilocus sequence typing (MLST).

Results: The genes for PVL were detected in $67 / 214$ (31.3\%) of S. aureus isolates. Majority of the PVL-positive isolates were obtained from wound $(n=37 ; 55.2 \%)$, blood $(n=11 ; 16.4 \%)$ and urine $(n=10 ; 14.9)$. Most of PVL-positive isolates $(\mathrm{n}=58 ; 34.7 \%)$ were methicillin sensitive $S$. aureus (MSSA) while nine isolates $(19.1 \%)$ were methicillin resistant $S$. aureus (MRSA). Spa typing identified 14 different spa types, dominated by t355 (n=33; 49.3\%), followed by t174 (n=7; $10.4 \%), t 019$ and 1159 ( $n=5 ; 7.5 \%)$. MLST revealed six sequence types (ST) namely, ST152 ( $n=35)$, ST121 (n=9), ST1 $(n=8)$, ST30 $(n=8)$, ST772 $(n=6)$ and ST15 $(N=1)$.

Conclusion: This study revealed that $31.3 \%$ of $S$. aureus isolated in Jos hospitals carried genes for PVL, belonged to six sequence types and 14 spa types with t355-ST152-MSSA as the dominant genotype.

Keywords: Staphylococcus aureus; Panton Valentine Leukocidin; Polymerase chain reaction; Spa typing; Multilocus sequence typing

\section{Introduction}

Staphylococcus aureus remains an important opportunistic pathogen that cause a wide range of infections in humans and animals. In humans, infections caused by $S$. aureus vary from skin lesions to severe invasive infections including

\footnotetext{
${ }^{*}$ Corresponding author: Unyime C Essien

Department of Medical Laboratory Science, Faculty of Health Sciences and Technology, University of Jos, Nigeria.

Copyright (C) 2021 Author(s) retain the copyright of this article. This article is published under the terms of the Creative Commons Attribution Liscense 4.0.
} 
bloodstream infections, necrotizing pneumonia and endocarditis [1]. The capacity of $S$. aureus to cause severe infections is due to their ability to express a wide variety of virulence factors that facilitate adhesion, invasion, and evasion of the host's immune system [2, 3].

Panton Valentine leukocidin (PVL) is a pore forming cytotoxin that causes destruction of leucocytes and tissue necrosis

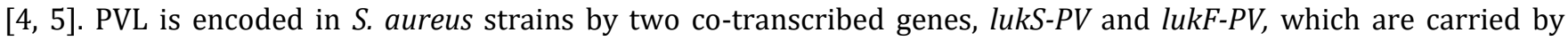
bacteriophages $[6,7]$. PVL producing $S$. aureus was originally associated with pus formation, carbuncles, furuncles severe skin and soft tissue infection (SSTI), necrotizing pneumonia and sepsis $[4,8]$.

The prevalence of PVL-producing $S$. aureus varies in different countries including African countries [9, 10, 11]. The proportion of $S$. aureus that carry the genes for PVL gene in Nigeria have been investigated in isolates obtained in the South West [12] and North East [13,14] of the country. Data on the prevalence of PVL-producing S. aureus in the North Central region of Nigeria is currently unavailable.

In this study we investigated $S$. aureus isolates obtained in tertiary hospitals in Jos, North Central Nigeria for the carriage of genes for PVL and their genetic background.

\section{Material and methods}

\subsection{Ethical approval}

This study was approved by the Ethical Committees of Jos University Teaching Hospital, Jos (JUTH) (Approval No. JUTH/DCS/ADM/127/XXV/314), Plateau State Specialist Hospital, Jos (PSSH) (Approval No. PSSH/ADM/ETH.CO/2017/006) and Bingham University Teaching Hospital, Jos, Plateau State (BUTH) (Approval No. NHREC/21/05/2005/00495).

\subsection{Sources and identification of bacterial isolates}

S. aureus $(\mathrm{n}=214 ; \mathrm{MRSA}=47, \mathrm{MSSA}=167)$ used in the study were cultured from different clinical specimens collected from three tertiary hospitals (JUTH=126; PSSH=66; BUTH=22) within the period of December 2017 to July 2019 in Jos, North Central Nigeria. These isolates were collected as part of routine bacteriological diagnostic investigations in the hospitals. The isolates were preserved in semi-solid agar medium ( $0.3 \%$ agar in brain heart infusion broth). They were re-tested and confirmed for growth and fermentation on mannitol salt agar, Gram stain, and positive results for catalase and tube coagulase tests at the Gram-Positive Bacteria Research Laboratory, Department of Microbiology, Faculty of Medicine, and Kuwait University, where the molecular studies were performed.

\subsection{Antibiotic susceptibility testing}

Antibiotic susceptibility testing was performed by the disc diffusion method according to the Clinical Laboratory Standard Institute [15]. Pure colonies of an overnight culture were suspended in normal saline and adjusted to a turbidity equivalent to $0.5 \mathrm{X}$ MacFarland standard $\left(1.5 \times 10^{8} \mathrm{CFU} / \mathrm{ml}\right)$. The suspension was poured on to Mueller-Hinton agar (MHA) (Oxoid, UK) plates and excess fluid was discarded and plates left to dry. Antibiotic discs were placed on the dried surface and the plates were incubated at $37^{\circ} \mathrm{C}$ for 24 hours. S. aureus strain, ATCC 25923, was used as control for sensitivity testing. The inhibition zone around each disc was measured and interpreted according to the Clinical Laboratory Standards Institute [15]. Sensitivity to fusidic acid by disc diffusion method was interpreted according [16], Sensitive $\geq 24$, and resistance $\leq 20$. The following antibiotic impregnated discs were used for sensitivity testing; cefoxitin $(30 \mu \mathrm{g})$, penicillin $(2 \mu \mathrm{g})$, gentamicin $(10 \mu \mathrm{g})$, kanamycin $(30 \mu \mathrm{g})$, erythromycin $(15 \mu \mathrm{g})$, clindamycin $(2 \mu \mathrm{g})$, chloramphenicol $(30 \mu \mathrm{g})$, tetracycline $(30 \mu \mathrm{g})$, trimethoprim $(5 \mu \mathrm{g})$, rifampicin $(15 \mu \mathrm{g})$, spectinomycin $(25 \mu \mathrm{g})$, fusidic acid $(10 \mu \mathrm{g})$, ciprofloxacin ( $5 \mu \mathrm{g})$, and mupirocin $(200 \mu \mathrm{g})$ (OXOID, UK, Ltd.). Susceptibility to three non-antibiotic compounds, cadmium acetate, mercuric chloride and ethidium bromide, were also tested. The heavy metals and ethidium bromide impregnated discs were prepared in the laboratory with the indicated concentrations: cadmium acetate (50 $\mu$ ), mercuric chloride, $(109 \mu \mathrm{g})$ and ethidium bromide $(50 \mu \mathrm{g})$. S. aureus WBG 248 [17] was used as quality control strain to compare its inhibition zone to the test organism. Minimum inhibitory concentrations of cefoxitin, vancomycin, teicoplanin, and mupirocin were determined using Etest strips (BioMerieux, Marcy" Etoile, France). Methicillin resistance was confirmed by the detection of PBP2a with a rapid latex agglutination test (Denka Seiken, Tokyo, Japan) following instructions of the manufacturer. 


\subsection{Molecular analysis of $S$. aureus isolates}

\subsubsection{Extraction of S. aureus DNA for PCR}

DNA isolation was carried out according to the method described by [18]. Three to five identical colonies of an overnight culture were picked using a sterile loop and suspended in a microfuge tube containing $50 \mu \mathrm{l}$ of lysostaphin $(150 \mu \mathrm{g} / \mathrm{ml})$ and $10 \mu \mathrm{l}$ of RNase $(10 \mu \mathrm{g} / \mathrm{ml})$ solution. The tube was incubated at $37^{\circ} \mathrm{C}$ in the heating block (Thermo Mixer, Eppendorf, Hamburg, Germany) for $20 \mathrm{~min}$. To each sample, $50 \mu \mathrm{l}$ of proteinase $\mathrm{K}(20 \mathrm{mg} / \mathrm{ml})$ and $150 \mu \mathrm{l}$ of Tris buffer $(0.1 \mathrm{M})$ were added and mixed by pipetting. The tube was then incubated at $60^{\circ} \mathrm{C}$ in the water bath (VWR Scientific Co., Shellware Lab, United States) for $10 \mathrm{~min}$. The tube was transferred to a heating block at $95^{\circ} \mathrm{C}$ for 10 min to inactivate proteinase $\mathrm{K}$ activity. Finally, the tube was centrifuged, and the extracted DNA was stored at $4{ }^{\circ} \mathrm{C}$ till used for PCR.

\subsubsection{Preparation of agarose gel}

Gel electrophoresis was used to separate DNA on the basis of their sizes by applying an electric field to move the DNA through an agarose matrix. Two $2 \%(\mathrm{w} / \mathrm{v})$ concentration of agarose gel used in the study was prepared by weighing and dissolving 4 grams of agarose powder (Promega, Madison, USA) in $200 \mathrm{ml}$ Tris-Borate-EDTA (1XTBE buffer) (Gibco, UK) using microwaved oven. The mixture was heated in a microwave oven until it became clear and transparent. The molten agarose was allowed to cool to about $45^{\circ} \mathrm{C}$ and $300 \mu \mathrm{l}(1 \mathrm{mg} / \mathrm{ml})$ of ethidium bromide was added to the gel. The molten gel was gently poured in a mould (casting), and was allowed to solidify after which the comb was removed to create wells for DNA sample application. The gel was transferred from the mould into an electrophoretic chamber (BioRad, USA) filled with (1x TBE) buffer.

\subsubsection{Detection of lukS-PV and lukF-PV by PCR}

The presence of lukS-PV and lukF-PV genes encoding Panton-Valentine leukocidin (PVL) was detected by PCR according to the method described by [4]. The $25 \mu \mathrm{l}$ volume of PCR reaction mixture consisted of $1.5 \mu \mathrm{l}$ of genomic DNA, $12.5 \mu \mathrm{l}$ of Hot Star Red Taq Master Mix and $10 \mu \mathrm{l} \mathrm{PCR} \mathrm{H}_{2} \mathrm{O}, 0.5 \mu$ l each of lukS-PV/ lukF-PV primers (Qiagen, Hilden, Germany). PVL gene was amplified using the following primers: luk-PV-1 (5'-ATC ATT AGG TAA AAT GTC TGG ACA TGA TCC A-3'); lukPV-2 (5'-GCA TCA AST GTA TTG GAT AGC AAA AGC -3'). In each batch of the PCR reaction, PVL positive DNA sample and PCR water were added as PCR positive and negative control respectively. DNA amplification was carried out for 30 cycles according to the following protocol: $30 \mathrm{~s}$ of denaturation at $94^{\circ} \mathrm{C}, 30 \mathrm{~s}$ of annealing at $55^{\circ} \mathrm{C}$, and 1 min of extension at $72^{\circ} \mathrm{C}$. Ten microlitres $(10 \mu \mathrm{l})$ of each PCR product and the controls were mixed each with $3 \mu \mathrm{l}$ of tracking dye (bromophenol blue) in a PCR tube and transferred by pipetting into the wells of $2 \%(\mathrm{w} / \mathrm{v})$ agarose gels. The electrophoretic chamber was connected to the power source and maintained at $90 \mathrm{~V}$ for 30 minutes. The gel was transferred to transilluminator and visualized by illumination with UV light. The DNA bands were viewed and recorded by photography using computer system (SynGene Bioimaging System) (Figure 3).

\subsubsection{Spa typing}

Spa typing was performed as described previously by [19]. The PCR protocol consisted of an initial denaturation at 94 ${ }^{\circ} \mathrm{C}$ for $4 \mathrm{~min}$, followed by 25 cycles of denaturation at $94{ }^{\circ} \mathrm{C}$ for $1 \mathrm{~min}$, annealing at $56^{\circ} \mathrm{C}$ for $1 \mathrm{~min}$, and extension for 3 min at $72^{\circ} \mathrm{C}$, and a final cycle with a single extension for $5 \mathrm{~min}$ at $72^{\circ} \mathrm{C}$. Five $\mu \mathrm{l}$ of the PCR product was analyzed by $1.5 \%$ agarose gel electrophoresis to confirm amplification. The amplified PCR product was purified using Micro Elute CyclePure Spin kit (Omega Bio-tek, Inc. USA) and the purified DNA was then used for sequencing PCR. The sequencing PCR product was then purified using Ultra-Sep Dye Terminator Removal kit (Omega Bio-tek, Inc. USA). The Purified DNA was sequenced in an automated 3130x1 genetic analyzer (Applied Biosystem, USA). The sequenced spa gene was analyzed using the Ridom Staph Type software available on Ridom SpaServer at https//spaserver.ridom.de.

\subsubsection{Multilocus sequence typing}

The MLST was performed on isolates using the method previously described by [20]. MLST was performed by initial amplification and sequencing of seven housekeeping genes in each isolate. The sequencing PCR protocol consisted of initial denaturation for $1 \mathrm{~min}$ at $94^{\circ} \mathrm{C}$, followed by 25 cycles of denaturation for $10 \mathrm{~s}$ at $96^{\circ} \mathrm{C}$, annealing at $55^{\circ} \mathrm{C}$ for $5 \mathrm{~s}$, and extension for $4 \mathrm{~min}$ at $66^{\circ} \mathrm{C}$. DNA sequencing was performed using a 3130x1 genetic analyzer (Applied Biosystems, Foster City, CA, USA) in accordance with the manufacturer's protocol. The sequences were submitted to http://www.pubmlst.net/ where an allelic profile was generated and the sequence type (ST) assigned. 


\subsubsection{Statistical analysis}

Data obtained from this study were analyzed using Statistical Package for the Social Sciences (SPSS) version 26.0. The presence of PVL gene MSSA, MRSA, sources of isolate and hospitals were compared using Pearson chi-square tests. Results were presented in tables, bar chart and percentages. P-values of $<0.05$ were considered statistically significant.

\section{Results}

\subsection{Prevalence of PVL-positive $S$, aureus according to clinical sources}

A total of $214 S$. aureus isolates were investigated by PCR to detect the carriage of $l u k F-P V$ - lukS-PV that codes for PVL. The results revealed that $67 / 214$ (31.3\%) S. aureus isolates were positive for lukS-PV /lukF-PV (Figure 1). The 67 PVLgene positive isolates were analyzed further in this paper. LukS-PV and lukF-PV was detected in $S$. aureus isolates obtained from 10 of 14 clinical samples. The distribution of lukS-PV and lukF-PV by clinical samples is illustrated in Figure 1. Most of the PVL-positive S. aureus isolates were cultured from wounds (n=37; 55.2\%), blood (n=11; 16.4\%) and urines $(\mathrm{n}=10 ; 14.9)$. The remaining PVL-positive $S$. aureus isolates were recovered from catheter tip (n=2; $2.9 \%)$, HVS $(\mathrm{N}=2 ; 2.9 \%)$, and in single isolates each obtained from aspirate, CSF, ear swab, throat swab and umbilical cord specimens (Figure 2).

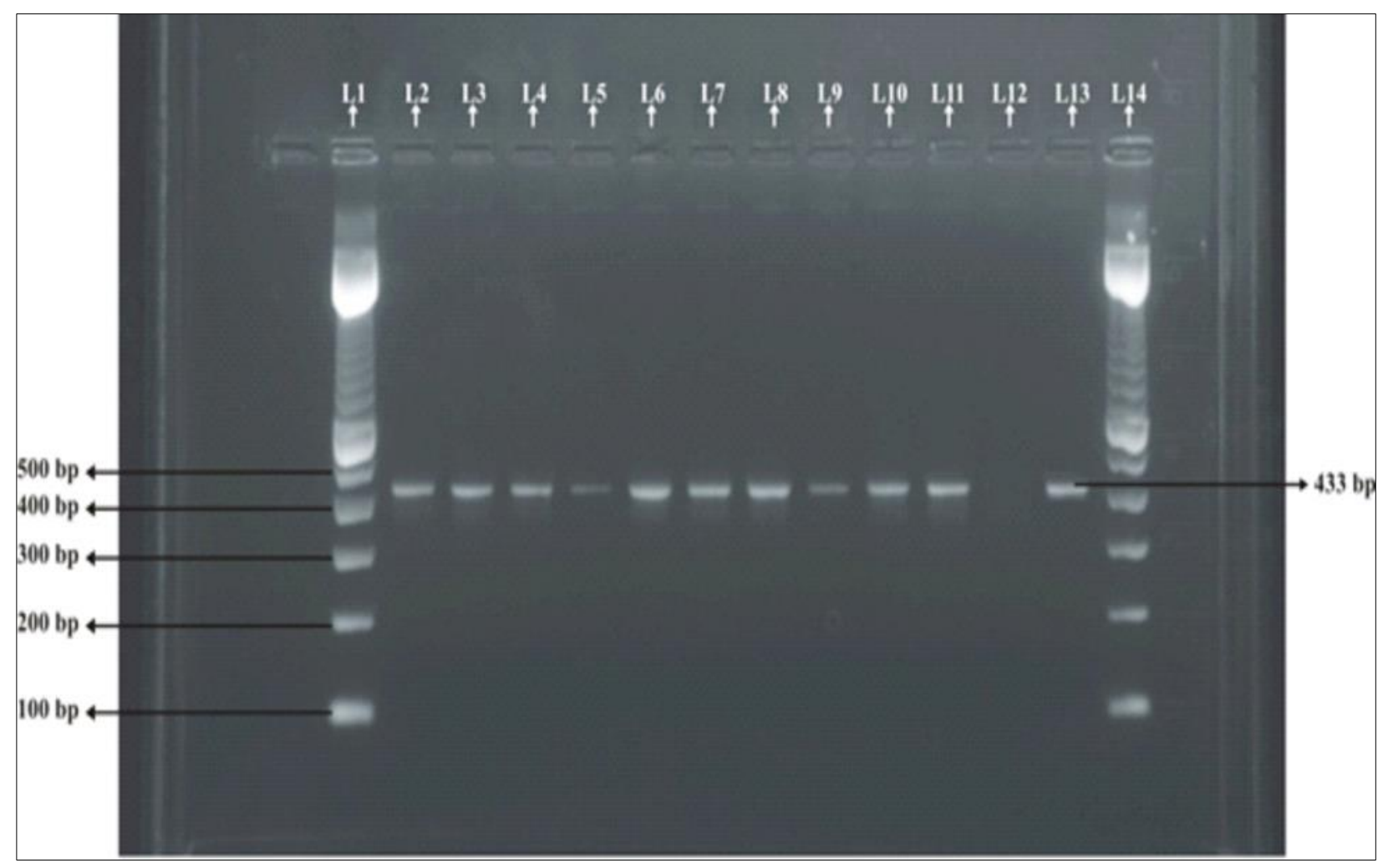

Figure 1 Agarose gel electrophoresis used for detection of amplified lukSF-PV gene by PCR. Lane 2, 3, 4, 5, 6, 7, 8, 9, 10 and 11 represents DNA bands from test samples positive for lukSF-PV. Lane 12 and 13 represents negative and positive lukSF-PV control sample respectively. The lane 1 and 14 represents $100 \mathrm{bp}$ DNA molecular ladder which was used for sizing DNA bands. However, the lukSF-PV gene is a 433 bp (amplicon size) DNA, therefore it was located between $400 \mathrm{bp}$ and 500bp. 


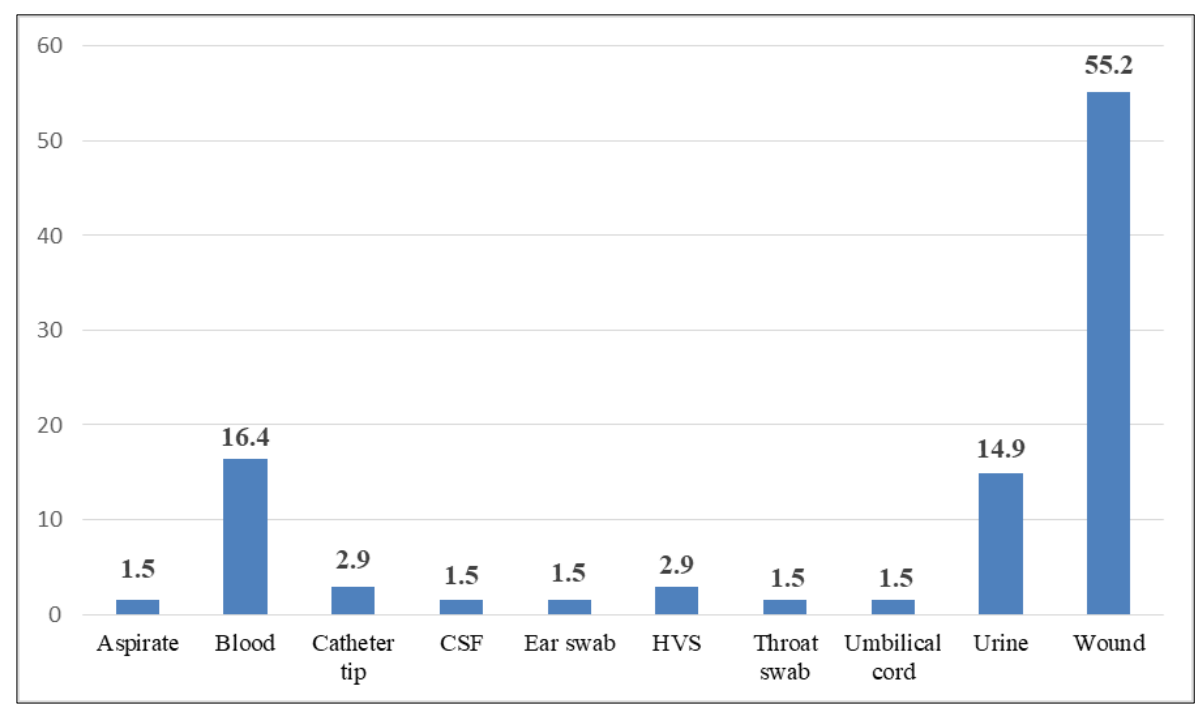

Figure 2 Prevalence of PVL-positive S. aureus according to clinical sources

\subsection{Prevalence of PVL-positive S. aureus according to hospitals, MSSA and MRSA}

The PVL gene was detected in S. aureus isolates obtained in all three hospitals, although the proportion of PVL-positive isolates varied among the hospitals. The proportion of PVL-positive isolates was lower in isolates obtained from PSSH $(\mathrm{N}=12 ; 18.2 \%)$ compared to those obtained from BUTH $(\mathrm{N}=7 ; 31.8 \%)$, and JUTH $(\mathrm{N}=48 ; 38.1 \%)$. However, the differences in the proportion of isolates carrying PVL genes according to hospitals were not statistically significant $(\mathrm{P}=0.600 ; \mathrm{P}>0.05)$. Also, most of PVL-positive isolates ( $\mathrm{n}=58 ; 34.7 \%)$ were MSSA (Table 1$)$.

Table 1. Prevalence of PVL-positive S. aureus according to hospitals, MSSA and MRSA

\begin{tabular}{|l|c|c|c|}
\hline Variables & No. of isolates & PVL positive isolates N (\%) & P-value \\
\hline Hospital & & & 0.600 \\
\hline BUTH & 22 & $7(31.8)$ & \\
\hline JUTH & 126 & $48(38.1)$ & \\
\hline PSSH & 66 & $12(18.2)$ & \\
\hline Strains & & & 0.010 \\
\hline MRSA & 47 & $9(19.1)$ & \\
\hline MSSA & 167 & $58(34.7)$ & \\
\hline
\end{tabular}

BUTH=Bingham University Teaching Hospital, JUTH=Jos University Teaching Hospital, PSSH=Plateau State Specialist Hospital

\subsection{Antimicrobial resistance of $l u k S-P V$ and $l u k F-P V$-positive isolates}

The antimicrobial resistance of the PVL-positive S. aureus isolates is presented in Figure 3. All 67 isolates were sensitive to vancomycin ( $\mathrm{MIC} \leq 2 \mu \mathrm{g} / \mathrm{ml}$ ), teicoplanin (MIC $\leq 2 \mu \mathrm{g} / \mathrm{ml}$ ), rifampicin, mupirocin, spectinomycin and chloramphenicol but were resistant to penicillin 60/67 (89.6\%) and trimethoprim 50/67 (74.6\%). Fifteen isolates (22.4\%) were resistant to ciprofloxacin. Tetracycline resistance was found in $13(19.4 \%)$ isolates. Nine $(13.4 \%)$ isolates each were resistant to cefoxitin, gentamicin and kanamycin. Erythromycin resistance was detected in two $(2.9 \%)$ isolates, while fusidic acid resistance was found in a single (1.5\%) isolate. Resistance to non-antibiotic agents were as follows; cadmium acetate 44 (65.7\%), mercuric chloride 19 (28.4\%) and ethidium bromide 8 (11.9\%). The cefoxitin-resistant isolates were positive for PBP $2 \mathrm{a}$ and were therefore confirmed as methicillin-resistant.

Nine MRSA isolates (19.1\%) were positive for PVL gene, while 58 (34.7\%) of MSSA isolates were PVL-positive. 


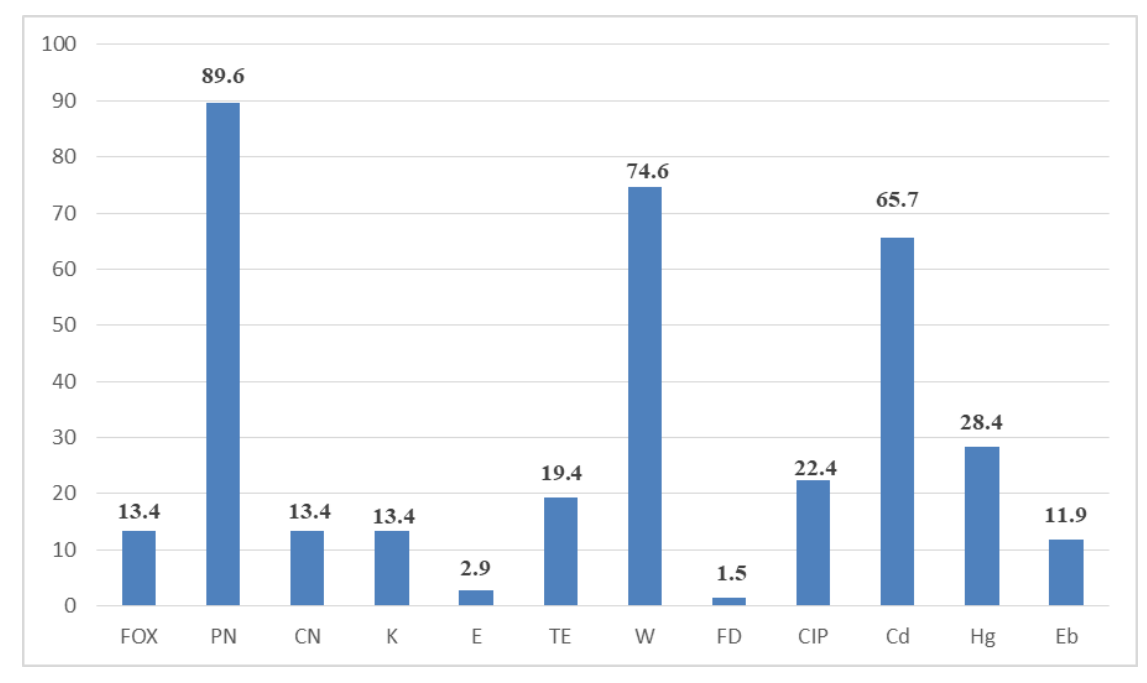

Figure 3 Antimicrobial resistance profile of PVL-positive isolates

FOX, Cefoxitin, PN, Penicillin G, CN, Gentamicin, K, Kanamycin, E, Erythromycin, TE, Tetracycline, W, Trimethoprim, FD, Fusidic acid, CIP, Ciprofloxacin, Cd, Cadmium acetate, Hg, Mercuric chloride, Eb, Ethidium bromide.

\subsection{Molecular characterization of PVL-positive $S$. aureus (PPSA) isolates}

The molecular characteristics of the isolates are summarized in Table 2. Multilocus sequence typing of the 67 PPSA isolates identified six sequence types (ST). These were ST152 ( $\mathrm{n}=35)$, ST121 $(n=9)$, ST1 $(n=8)$, and ST30 (n=8), ST772 $(\mathrm{n}=6)$ and ST15 $(\mathrm{n}=1)$.

Spa typing revealed 14 spa types comprising $\mathrm{t} 355(\mathrm{n}=33 ; 49.3 \%), \mathrm{t} 174(\mathrm{n}=7 ; 10.4 \%), \mathrm{t} 019(\mathrm{n}=57 ; 5 \%), \mathrm{t} 159(\mathrm{n}=5 ; 7.5 \%)$ and $\mathrm{t} 345(\mathrm{~N}=4 ; 5.9 \%)$ as the common spa types. Spa types, t657, t037, t1991 and t18034 were each detected in $2(2.9 \%)$ isolates, and spa types, t127, t346, t318, t3488, and t2304 were each detected in single isolates.

The characteristics of isolates belonging to the different sequence types are presented below.

\subsubsection{ST772-MRSA, [PVL $\left.{ }^{+}\right]$}

The ST772-MRSA [ $\left.\mathrm{PVL}^{+}\right]$clone consisted of six isolates that were associated with two spa types, $\mathrm{t} 345(\mathrm{n}=4)$ and t657 $(\mathrm{n}=2)$. All six isolates were resistant to cefoxitin, penicillin, trimethoprim, gentamicin, kanamycin, erythromycin, and ciprofloxacin and cadmium acetate. In addition, two isolates belonging to ST772-MRSA-V [PVL $]+t 657$, were resistant to mercuric chloride, and one of the isolates was resistant to tetracycline.

\subsubsection{ST1-MSSA, $\left[\mathrm{PVL}^{+}\right]$}

The ST1-MSSA, [PVL+] clone consisted of eight MSSA isolates that belonged to spa types, t174 (n=7) and t127 (n=1). Six of the isolates were resistant to trimethoprim. Five and three isolates were resistant to penicillin and tetracycline respectively.

\subsubsection{ST15-MSSA [PVL $]$}

A single isolate was identified as ST15-MSSA [PVL+] clone. This isolate was cultured from a urine specimen. It belonged to spa type $\mathbf{3 4 6}$, and was resistant to trimethoprim, mercury chloride and ethidium bromide.

\subsubsection{ST30-MSSA, $\left[P V L^{+}\right]$}

Eight isolates were identified as ST30-MSSA, [PVL+]. The isolates were associated with spa types t019 (n=5), t037 (n=2) and t318 $(n=1)$. All eight isolates were resistant to penicillin. In addition, two isolates were resistant to ciprofloxacin.

\subsubsection{ST121-MSSA [PVL $\left.{ }^{+}\right]$}

The ST121-MSSA [PVL $\mathrm{PL}^{+}$clone consisted of nine isolates that were associated with spa types, t159 (n=5), t1991 (n=2), t3488 (n=1) and t2304 (n=1). All nine isolates were resistant to penicillin. Six isolates were resistant to trimethoprim. 


\subsubsection{ST152 -MRSA [PVL $]$ /ST152-MSSA [PVL $\left.{ }^{+}\right]$}

A total of 35 PVL-positive $S$. aureus isolates belonged to sequence type, ST152 with 32 of the isolates being ST152-MSSA and only three were ST152-MRSA. The 35 isolates belonged to spa types, t355 (n=33) and a novel spa type, t18034 $(\mathrm{n}=2)$. Apart from cefoxitin resistance observed in the three ST152-MRSA, [ $\left.\mathrm{PVL}^{+}\right]$isolates, all 35 isolates had the same resistance profiles and were resistant to penicillin, gentamicin, kanamycin, tetracycline, and trimethoprim. All three ST152-MRSA and 30 ST152-MSSA belonged to t355. Two ST152-MSSA isolates were associated with the novel spa type, $\mathrm{t} 18034$.

Table 2 Characteristics of PVL-positive isolates

\begin{tabular}{|c|c|c|c|}
\hline $\begin{array}{l}\text { Strain } \\
\text { Description }\end{array}$ & $\begin{array}{l}\text { Spa types } \\
\text { (N) }\end{array}$ & Clinical samples (N) & Antimicrobial resistance \\
\hline $\begin{array}{l}\text { ST772-MRSA } \\
{[\mathrm{PVL}+]}\end{array}$ & t345 (4) & Urine (1), Blood (1), Wound (2) & $\begin{array}{l}\text { FOX (4), P (4), CN (4), K (4), E (4), W (4), } \\
\text { CIP (4), CD (4). }\end{array}$ \\
\hline $\begin{array}{l}\text { ST772-MRSA } \\
{[\mathrm{PVL}+]}\end{array}$ & t657 (2) & Wound (2) & $\begin{array}{l}\text { FOX (2), P (2), CN (2), K (2), E (2), TE (1), } \\
\text { W (2), CIP (2), CD (2), Hg (2) }\end{array}$ \\
\hline $\begin{array}{l}\text { ST1-MSSA } \\
{[\mathrm{PVL}+]}\end{array}$ & t174 (7) & $\begin{array}{l}\text { Wound (4), Catheter (2), Umbilical } \\
\text { cord (1) }\end{array}$ & $\mathrm{P}(4), \mathrm{TE}(3), \mathrm{W}(5), \mathrm{CD}(3)$ \\
\hline $\begin{array}{l}\text { ST1-MSSA } \\
{[\mathrm{PVL}+]}\end{array}$ & t127 (1) & Urine (1) & $\mathrm{P}, \mathrm{W}, \mathrm{Hg}$ \\
\hline $\begin{array}{l}\text { ST15-MSSA } \\
{[\text { PVL+] }}\end{array}$ & t346 (1) & Urine (1) & $\mathrm{W}, \mathrm{Hg}, \mathrm{Eb}$ \\
\hline $\begin{array}{l}\text { ST30-MSSA } \\
{[\mathrm{PVL}+]}\end{array}$ & t019 (5) & Wound (3), Blood (2) & $P(5), C D(2)$ \\
\hline $\begin{array}{l}\text { ST30-MSSA } \\
{[\mathrm{PVL}+]}\end{array}$ & t037 (2) & Blood (1), Wound (1). & $\begin{array}{l}\text { P (2), CIP (2), TE (1), CD (2), Hg (2), Eb } \\
(2)\end{array}$ \\
\hline $\begin{array}{l}\text { ST30-MSSA } \\
{[\mathrm{PVL}+]}\end{array}$ & t318 (1) & Wound (1) & $\mathrm{P}, \mathrm{W}, \mathrm{CD}, \mathrm{Eb}$ \\
\hline $\begin{array}{l}\text { ST121- } \\
\text { MSSA[PVL+] }\end{array}$ & t159(5) & Wound (2), Bood (2), Ear swab & $\mathrm{P}(5), \mathrm{W}(4), \mathrm{CD}(1)$ \\
\hline $\begin{array}{l}\text { ST121- } \\
\text { MSSA[PVL+] }\end{array}$ & t1991 (2) & HVS (1), Aspirate (1) & $\mathrm{P}(2), \mathrm{CD}(2), \mathrm{Hg}(2)$ \\
\hline $\begin{array}{l}\text { ST121- } \\
\text { MSSA[PVL+] }\end{array}$ & $\mathrm{t} 3488(1)$ & Wound (1) & $\mathrm{P}, \mathrm{W}, \mathrm{CD}, \mathrm{Hg}$ \\
\hline $\begin{array}{l}\text { ST121- } \\
\text { MSSA[PVL+] }\end{array}$ & $\mathrm{t} 2304(1)$ & Urine (1) & $\mathrm{P}, \mathrm{W}, \mathrm{Hg}$ \\
\hline $\begin{array}{l}\text { ST152- } \\
\text { MRSA[PVL+] }\end{array}$ & t355 (3) & Wound (3) & $\begin{array}{l}\text { FOX (3), P (3), CN (2), K (2), CD (3), TE } \\
\text { (1) }\end{array}$ \\
\hline $\begin{array}{l}\text { ST152-MSSA } \\
{[\mathrm{PVL}+]}\end{array}$ & $\mathrm{t} 355(30)$ & $\begin{array}{l}\text { Wound (18), Urine (5), Blood } \\
(4), \operatorname{HVS}(1), \operatorname{CSF}(1) \text {, Throat (1) }\end{array}$ & $\begin{array}{l}\text { P (27), W (25), TE (5), CIP (7), CN (1), K } \\
(1), C D(21), \mathrm{Hg}(7), \mathrm{Eb}(4), \mathrm{FD}(1) .\end{array}$ \\
\hline $\begin{array}{l}\text { ST152-MSSA } \\
{[\mathrm{PVL}+]}\end{array}$ & $\begin{array}{l}\mathrm{t} 18034 \\
(2)\end{array}$ & Urine (1), Blood (1) & $\mathrm{P}(2), \mathrm{TE}(2), \mathrm{W}(2), \mathrm{CD}(2), \operatorname{Hg}(2), \mathrm{Eb}(1)$ \\
\hline
\end{tabular}

Abbreviations: FOX, Cefoxitin, PN, Penicillin G, CN, Gentamicin, K, Kanamycin, E, Erythromycin, TE, Tetracycline, W, Trimethoprim, FD, Fusidic acid, CIP, Ciprofloxacin, Cd, Cadmium acetate, $\mathrm{Hg}$, Mercuric chloride, Eb, Ethidium bromide. 


\section{Discussion}

Some $S$. aureus strains cause severe infections because of the diverse virulence factors at their disposal which enhance their invasiveness, evasion of host immune facilities and capacity to cause tissue damage [10, 21]. PVL is one of the virulence factors that enhance bacterial virulence by destroying human tissues and white blood cells [4, 5]. Knowledge of the carriage of the genes for PVL in S. aureus enhances our understanding of their capacity to cause infections.

Our study detected the genes for PVL in 31.3\% of the $S$. aureus isolates obtained from three tertiary hospitals in Jos, North Central Nigeria. This result concurs with the 34.6\% prevalence reported previously in S. aureus obtained in South West Nigeria [22], and the 39.3\% prevalence reported among clinical S. aureus isolates obtained from Obafemi Awolowo Teaching Hospital, Nigeria [23]. Similarly, PVL-positive strains accounted for $36 \%$ of $S$. aureus investigated in a study in USA [24]. Our result was lower than the proportion of PVL-positive $S$. aureus reported in Maiduguri, North East Nigeria (52.1\%) [13]; the 61.4\% in the Gambia [25], the 58\% in Sudan [26], the 73.91\% in Colombia [27], the 61.5\% in India [28], the 56.2\% in Iran [29], the $46.3 \%$ in Kazakhstan [30] and the $62.5 \%$ in Trinidad and Tobago [31]. In contrast, our result was higher than the prevalence of PVL-positive strains reported from several other studies in Abuja, Nigeria that reported a prevalence of $10.7 \%$ among isolates obtained from Maitama District Hospital [14], the 12.7\% prevalence reported in Kuwait [8], the 23\% reported in Iran [32] and the 18.6\% prevalence reported in Brazil [33]. These studies suggest geographical differences in the prevalence of PVL-positive $S$. aureus.

The PVL-positive $S$. aureus were grown from different clinical samples including wounds, Blood, respiratory samples, and a variety of other samples except eye swab, nasal swab, semen, and urethral swab. Previously PVL-producing $S$. aureus were associated with skin and soft tissue infections, and necrotizing pneumonia [4,5]. Despite the small numbers of PVL-positive $S$. aureus in this study, their presence in a range of clinical samples indicates their capacity to cause a wider range of infections than were previously reported.

Most of the PVL-positive isolates in this study (58/167; 34.7\%) were MSSA with only 19.1\% (9/47) being MRSA. This confirmed the results of previous studies conducted in Nigeria [22] that reported more PVL-positive strains among MSSA (53.3\%) compared to 9.1\% in MRSA isolates. Similarly, PVL was positive in 63\% of MSSA and in 37\% MRSA that were investigated in a study in Iran [32]. In contrast, higher PVL-positive strains were reported in MRSA (14.6\%) than in MSSA (12.0\%) in Kuwait [8], and MRSA (80.92\%) and MSSA (67.59\%) in Colombia [27]. These results further suggest geographic differences in the distribution of PVL-positive $S$. aureus strains.

The PVL-positive isolates in this study belonged to diverse genetic backgrounds with most belonging to ST152 and t355. Similarly, studies in many countries in Africa including Nigeria [12, 34], Mali [35], Cameroon [9], Ghana [11], Senegal [36], Gabon [37] and Burkina Faso [38] have reported ST152 as the dominant sequence type in these countries.

The three PVL-positive ST152-MRSA and 30 ST152-MSSA isolates belonged spa type t355 and were resistant to gentamicin and tetracycline suggesting that the PVL-positive MRSA could have evolved through the acquisition of $m e c A$, that confers methicillin resistance, by ST152 -MSSA isolates. A study conducted in Kuwait[39], identified PVL-positive ST152-MRSA-V isolates, that were also resistant to gentamicin, tetracycline, and trimethoprim suggesting that resistance to gentamicin and tetracycline may be a common characteristic of ST152 isolates.

ST121-MSSA [PVL+] was the second common PVL- positive S. aureus isolates in this study. The isolates were recovered from wound, blood culture, HVS, urine, aspirate and ear swab indicating that ST121-MSSA can cause a wide range of infections in contrast to their earlier association only with skin and soft tissue infections [40]. The nine (ST121-MSSA $\left.\left[\mathrm{PVL}^{+}\right]\right)$isolates belonged to different spa types: $\mathrm{t} 159(\mathrm{n}=5), \mathrm{t} 1991(\mathrm{n}=2), \mathrm{t} 3488(\mathrm{n}=1)$ and t2304 (n=1) suggesting an emerging genetic diversification of the ST121-MSSA [PVL ${ }^{+}$] strain in Jos, Nigeria. The ST121-MSSA [PVL'] clone has also been reported from other hospitals in Nigeria [23,12], Burkina Faso [38], Cameroon [9], France [41], South Africa [42], Myanmar [43] and Italy [44] confirming the global presence of this clone [40].

The other common strain was the ST30-MSSA, [PVL ${ }^{+}$lineage, which has also been reported in China [45] and Lebanon [46] to be similar to MSSA clade that evolved into the Southwest Pacific MRSA clone of community-associated MRSA $[47,48,49,40]$.

The ST1-MSSA [PVL+] isolates in this study were associated with spa types, t174, and t127. Whereas t127 is widely reported in association with ST1-MSSA, [PVL+] in Malaysia [50], Lebanon [46], and Chicago [51], ST1-MSSA belonging to 1174 are widespread and have been isolated in different countries including Germany, South Africa, Iceland, Austria, Ireland, Netherland and United Kingdom (www.spa.ridom.de/spa-t174.shtml). 
The ST772-MRSA-V [PVL+], also known as the Bengal Bay Clone, is a multi-resistant PVL-positive MRSA that was initially isolated in Bangladesh and India between 2004 and 2005 [52]. However, the ST772-MRSA-V [PVL+] clone has been reported in other countries including Ireland [53], Saudi Arabia [54], Hong Kong [40], Nepal [55], Italy [56], New Zealand [57], and Kuwait [58]. The transmission of the Bengal Bay clone outside India has been associated with travel history to or from India [59, 60, 40]. The Bengal Bay clone described previously in Nigeria [61] among $S$. aureus isolates was recovered from patients in Lagos State University Teaching Hospital. The report of the ST772-MRSA [PVL+] in this study represents an expansion of this clone in Nigeria. The six ST772-MRSA [PVL+] isolates were resistant to cefoxitin, penicillin, gentamicin, erythromycin, kanamycin, trimethoprim and tetracycline, similar to the isolates obtained in India $[62,63]$ and Norway [64]. Although it is not possible to establish how this strain was introduced into Jos, this report suggests a possible importation of the Bengal Bay MRSA clone into Jos and other parts of Nigeria.

Although a single isolate of PVL-positive ST15-MSSA lineage was obtained in this study, the ST15-MSSA is widespread and was detected previously among isolates obtained from human patients [23, 12,34] and animals [65] in Nigeria. ST15-MSSA [PVL+] isolates were also reported in $S$. aureus that were isolated from skin infection of asylum seekers in Switzerland [66] and in S. aureus submitted to the Staphylococcus reference center in France [41] supporting that this clone is widespread globally.

\section{Conclusion}

This study has revealed the rate of carriage of PVL gene among clinical S. aureus in Jos's hospitals. In addition, the frequency of PVL genes was higher in MSSA isolates compared to MRSA and most of the PVL-positive isolates belonged to diverse genetic backgrounds and cause a wide range infection.

\section{Compliance with ethical standards}

\section{Acknowledgments}

We thank the management of Jos University Teaching Hospital, Jos, Plateau State Specialist Hospital, Jos and Bingham University Teaching Hospital, Jos for giving approval for the study. Also, we are grateful to Mr. Nnamdi Uzoma and Mr. Ezra Dasun of the Department of Medical Laboratory Science University of Jos for their technical assistance.

\section{Authors Contributions}

Conceptualization: Edet E. Udo; Investigation: Samar S. Boswihi, Unyime C. Essien; Methodology: Samar S. Boswihi, Unyime C. Essien; Supervision: Edet E. Udo, Nneka R. Agbakoba; Writing-original draft: Unyime C. Essien; Writingreview and editing: Edet E. Udo, Unyime C. Essien, Samar S. Boswihi, Nneka R. Agbakoba.

\section{Disclosure of conflict of interest}

We have no conflict of interest to disclose.

\section{References}

[1] Josse J, Velard F, Gangloff SC. Staphylococcus aureus vs. Osteoblast: Relationship and Consequences in Osteomyelitis. Frontiers in Cellular and Infection Microbiology. 2015; 5(85): 1-17.

[2] Josse J, Laurent F, Diot, A. Staphylococcal Adhesion and Host Cell Invasion: Fibronectin-Binding and Other Mechanisms. Frontiers in Microbiology. 2017; 8: 2433. 1-8.

[3] Foster CE, Kok M, Flores AR, Minard CG, Luna RA, Lamberth LB, Kaplan SL, Hulten KG. Adhesin genes and biofilm formation among pediatric Staphylococcus aureus isolates from implant associated infections. PLoS ONE. 2020; 5(6): $1-11$.

[4] Lina G, Piemont Y, Godail-Gamot F, Bes M, Peter MO, Gauduchon V, Vandenesch F, Etienne J. Involvement of Panton-Valentine leukocidin-producing Staphylococcus aureus in primary skin infections and pneumonia. Clinical Infectious Diseases. 1999; 29(5): 1128-32.

[5] Gillet Y, Issartel B, Vanhems P, Fournet J, Lina G, Bes M, Vandenesch F, Piemont Y, Brousse N, Floret D, Etienne J. Association between Staphylococcus aureus strains carrying gene for Panton-Valentine leukocidin and highly lethal necrotising pneumonia in young immunocompetent patients. Lancet. 2002; 359(9308): 753-9. 
[6] Okolie CE, Cockayne A, Penfold C, James R. Engineering of the LukS-PV and LukF-PV subunits of Staphylococcus aureus Panton-Valentine leukocidin for Diagnostic and Therapeutic Applications. BMC Biotechnology. 2013; 13(103): 1-13.

[7] Okolie CE, James R. Development of New Pentaplex PCR Assay for Differentiating Staphylococci from Other Bacteria with Simultaneous Detection of Staphylococcus aureus Genes Encoding Panton-Valentine Leukocidin and Methicillin Resistance. Journal of Advances in Biology \& Biotechnology. 2015; 2(4): 250-259.

[8] ALFouzan W, Al-Haddad A, Udo E, Bindu M, Dhar R. Frequency and Clinical Association of Panton-Valentine Leukocidin-Positive Staphylococcus aureus isolates: A Study from Kuwait. Medical Principle Practice. 2013; 22: 245-249.

[9] Breurec $S_{2}$ Fall C, Pouillot R, Boisier P, Brisse S, Diene-Sarr F, Djibo S, Etienne J, Fonkoua MC, Perrier-GrosClaude JD, Ramarokoto CE, Randrianirina F, Thiberge JM, Zriouil SB,_Working Group on Staphylococcus aureus Infections, Garin_B, Laurent F. Epidemiology of methicillin-susceptible Staphylococcusaureus lineages in five major African towns: high prevalence of Panton-Valentine leukocidin genes. Clinical Microbiology and Infection. $2011 ; 17(4): 633-639$.

[10] Schaumburg F, Ateba Ngoa U, Kosters K, Kock R, Adegnika AA, Kremsner PG, Lell B, Peters G, Mellmann A, Becker K. Virulence factors and genotypes of Staphylococcus aureus from infection and carriage in Gabon. Clinical Microbiology and Infection. 2011; 17(10): 1507-1513

[11] Egyir B, Guardabassi L, Sorum M, Nielsen SS, Kolekang A, Frimpong E, Addo KK, Newman MJ, Larsen AR. Molecular Epidemiology and Antimicrobial Susceptibility of Clinical Staphylococcus aureus from Healthcare Institutions in Ghana. PLoS One. 2014; 9(2): 1-7.

[12] Shittu AO, Okon K, Adesida S, Oyedara O, Witte W, Strommenger B, Layer F, Nubel U. Antibiotic resistance and molecular epidemiology of Staphylococcus aureus in Nigeria. BMC Microbiology. 5 May 2011; 11: 92.

[13] Okon KO, Uba A, Oyawoye OM, Yusuf IZ, Adesina 00. Prevalence and Antibiotic susceptibility pattern of PantonValentine Leucocidin (PVL) positive Staphylococcus aureus Strains from clinical specimens in Northeastern Nigeria. Sierra Leone Journal of Biomedical Research. 2012; 4(1): 43-52.

[14] Orji OL, Olayinka BO, Afolabi B, Ejikeugwu CP, Nwakaeze EA. Molecular Detection of Panton-Valentine Leukocidin (PVL) Toxins in Clinical Isolates of Staphylococcus aureus from Maitama District Hospital, Abuja, Nigeria. Journal of Medical Microbiology and Diagnosis. 2016; 5(240): 1-4.

[15] Clinical and Laboratory Standards Institute Performance Standards for Antimicrobial Susceptibility Testing; Twenty-Fourth Informational Supplement. Wayne, PA, USA: CLSI; 2017. M100-S24.

[16] Skov R, Frimodt-Moller N, Espersen F. Tentative interpretative zone diameters for fusidic acid Neosensitabs on Mueller Hinton agar and three blood containing media. International Journal of Antimicrobial agents. 2003; 22(5): 502-507.

[17] Townsend DE, Ashdown N, Greed LC, Grubb WB. Transposition of gentamicin resistance to Staphylococcal plasmids encoding resistance to cationic agents. Journal of Antimicrobial and Chemotherapy. 1984; 14(2): 115124.

[18] Udo EE, Farook VS, Mokaddas EM, Jacob LE, Sanyal SC. Molecular fingerprinting of mupirocin-resistant Staphylococcus aureus from a burn unit. International Journal of Infectious Diseases. 1999; 3(2): 82-87.

[19] Harmsen D, Claus H, Witte W, Rothganger J, Turnwald D, Vogel U. Typing of methicillin-resistant Staphylococcus aureus in a university hospital setting by using novel software for spa repeat determination and database management. Journal of Clinical Microbiology. 2003; 4 (12): 5442-5448.

[20] Enright MC, Day NPJ, Davies CE, Peacock SJ, Spratt BG. Multilocus sequence typing for characterization of methicillin-Resistant and methicillin susceptible clones of Staphylococcus aureus. Journal of Clinical Microbiology. 2000; 38(3): 1008-1015.

[21] Tong SY, Davis JS, Eichenberger E, Holland TL, Fowler VG. Staphylococcus aureus infections: epidemiology, pathophysiology, clinical manifestations, and management. Clinical Microbiology Reviews. 2015; 28(3): 603-61.

[22] Alli OA, Ogbolu DO, Shittu AO, Okorie AN, Akinola JO, Daniel JB. Association of virulence genes with mecA gene in Staphylococcus aureus from Tertiary Hospitals in Nigeria. Indian Journal of Pathology and Microbiology. 2015; 58(4): 464-467. 
[23] Kolawole DO, Adeyanju A, Schaumburg F, Akinyoola AL, Lawal O0, Amusa YB, Kock R, Becker K. Characterization of Colonizing Staphylococcus aureus Isolated from Surgical Wards' Patients in a Nigerian University Hospital. PLoS One. 2013; 8(7): 1-6.

[24] Brown ML, O'Hara PF, Close MN, Mera RM, Miller LA, Suaya JA, Amrine-Madsene H. Prevalence and Sequence Variation of Panton-Valentine Leukocidin in Methicillin-Resistant and Methicillin-Susceptible Staphylococcus aureus Strains in the United States. Journal of Clinical Microbiology. 2012; 50(1): 86 -90.

[25] Darboe S, Dobreniecki S, Jarju S, Jallow M, Mohammed $\mathrm{NI}_{\llcorner}$Wathuo $\mathrm{M}_{\llcorner}$Ceesay $\mathrm{B}_{\llcorner}$Tweed S, Basu Roy $\mathrm{R}_{\llcorner} \mathrm{Okomo} \mathrm{U}_{2}$

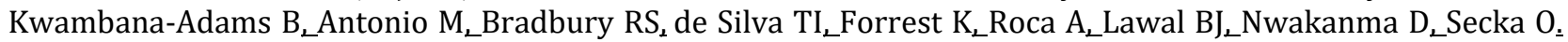
Prevalence of Panton-Valentine Leukocidin (PVL) and Antimicrobial Resistance in Community-Acquired Clinical Staphylococcus aureus in an Urban Gambian Hospital: A 11-Year Period Retrospective Pilot Study. Frontiers in Cellular and Infection Microbiology. 2019; 22(9): 1-9.

[26] Osman NM, Alrayah IE, Mohamed YM, Erag AE, Eldirdery MM, Salih MA. Molecular Study of Panton-Valentine Leukocidin Genes among Staphylococcus aureus Clinical Isolates in Khartoum State, Sudan. American Journal of Microbiological Research. 2015; 3(3): 107-111.

[27] Correa-Jimenez O, Pinzon-Redondo H, Reyes N. High frequency of Panton-Valentine leukocidin in Staphylococcus aureus causing pediatric infections in the city of Cartagena-Colombia. Journal of Infection and Public Health. 2015; 9(4): 415-420.

[28] Patil NR, Ghorpade MV. Association of Virulence Factor (Panton-Valentine Leukocidin) With Meca Gene in Staphylococcus aureus Isolates in Tertiary Care Hospital. Asian Journal of Pharmaceutical and Clinical Research. 2018; 11(2): 113-116.

[29] Nourbakhsh F, Borooni S, Tajbakhsh E. The Prevalence of Panton-Valentine Leukocidin Gene in Staphylococcus aureus Species Isolated from Nosocomial Infections in Isfahan, Iran. Avicenna Journal ofClinical Microbiology and Infection. 2018; 5(1): 1-4.

[30] Azizov I, Babenko D, Lavrinenko A, Zakharova Y, Bisenova N. Prevalence of PVL and Hlg genes in S. aureus isolated from patients with skin and soft tissue infections. International Journal of Infectious Diseases. 2014; 21(1): 1-8.

[31] Vire FP, Akpaka PE, Unaka C. Molecular characterization of methicillin-resistant Staphylococcus aureus isolates from rural community settings in Trinidad and Tobago. Nigerian Journal of Clinical Practice. 2018; 21(12): 15961601.

[32] Havaei SA, Poursina F, Ahmadpour M, Havaei SR, Ruzbahani M. Detection of Panton-valentine Leukocidin Gene Isoforms of Staphylococcus aureus Isolates in Al-Zahra Hospital, Isfahan-Iran. Advanced Biomedical Research. 2017; 6(1): 1-4.

[33] Rossato AM, Reiter KC, Alves d'Azevedo P. Co-existence of virulence genes in methicillin-resistant Staphylococcus aureus clinical isolates. Journal of the Brazilian Society of Tropical Medicine. 2017; 51(3): 361-363.

[34] Obasuyi O, McClure J, Oronsaye FE, Akerele JO, Conly J, Zhang, K. Molecular Characterization and Pathogenicity of Staphylococcus aureus Isolated from Benin-City, Nigeria. Microorganisms. 2020; 8(912): 1-19.

[35] Ruimy R, Maiga A, Armand-Lefevre L, Maiga I, Diallo A, Koumare AK, Ouattara K, Soumare S, Gaillard K, Lucet J, Andremont A, Feil J F. The carriage population of Staphylococcus aureus from Mali is composed of a combination of pandemic clones and the divergent Panton-Valentine leukocidin-positive genotype ST152. Journal of Bacteriology. 2008; 190(11): 3962-3968.

[36] Fall C, Seck A, Richard V, Ndour M, Sembene M, Laurent F, Breurec S. Epidemiology of Staphylococcus aureus in pigs and farmers in the largest farm in Dakar, Senegal. Foodborne Pathogens and Disease. 2012; 9(10): $962-965$.

[37] Schaumburg F, Alabi AS, Mombo-Ngoma G, Kaba H, Zoleko RM, Diop DA, Mackanga JR, Basra A, Gonzalez R, Menendez C, Grobusch MP, Kremsner PG, Kock R, Peters G, Ramharter M, Becker, K. Transmission of Staphylococcus aureus between mothers and infants in an African setting. Clinical Microbiology and Infection. 2014; 20(6): 390-396.

[38] Ouedraogo AS, Dunyach-Remy C, Kissou A, Sanou S, Poda A, Kyelem CG, Solassol J, Banuls AL, Van De Perre P, Ouedraogo R, Jean-Pierre H, Lavigne JP, Godreuil S. High Nasal Carriage Rate of Staphylococcus aureus Containing Panton-Valentine leukocidin- and EDIN-Encoding Genes in Community and Hospital Settings in Burkina Faso. Frontiers in Microbiology. 2016; 7(1406). 
[39] Boswihi SS, Udo EE. Methicillin resistance Staphylococcus aureus: An update on the epidemiology, treatment options and infection control. Current Medicine Research and Practice 2018; 8: 18-24.

[40] Monecke S, Coombs G, Shore AC, Coleman DC, Akpaka P, Borg M, Chow H, Ip M, Jatzwauk L, Jonas D, Kadlec K, Kearns A, Laurent F, O’Brien FG, Pearson J, Ruppelt A, Schwarz S, Scicluna E, Slickers P, Tan H, Weber S, Ehricht, R. A Field Guide to Pandemic, Epidemic and Sporadic Clones of Methicillin- Resistant Staphylococcus aureus. PLoS One. 2011; 6(4): 1-24.

[41] Rasigade J, Laurent F, Lina G, Meugnier H, Bes M, Vandenesch F, Etienne J, Tristan, A. Global Distribution and Evolution of Panton Valentine Leukocidin-Positive Methicillin-Susceptible Staphylococcus aureus, 1981-2007. The Journal of Infectious Diseases. 2010; 201(10): 1589-1597.

[42] Oosthuysen WF, Orth H, Lombard CJ, Sinha B, Wasserman E. Population structure analyses of Staphylococcus aureus at Tygerberg Hospital, South Africa, reveals a diverse population high prevalence of Panton-Valentine leukocidin genes and unique local MRSA clones. Clinical Microbiology and Infection. 2014; 20(7): 652-659.

[43] Aung MS, Urushibara N, Kawaguchiya M, Aung TS, Mya S, San T, Nwe KM, Kobayashi, N. Virulence factors and genetic characteristics of methicillin-resistant and susceptible Staphylococcus aureus isolates in Myanmar. Microbial Drug Resistance. 2011; 17(4): 525-35.

[44] Manara S, Pasolli E, Dolce D, Ravenni N, Campana S, Armanini F, Asnicar F, Mengoni A, Galli L, Montagnani C, Venturini E, Rota-Stabelli O, Grandi G, Taccetti G, Segata, N. Whole-genome epidemiology, characterization, and phylogenetic reconstruction of Staphylococcus aureus strains in a paediatric hospital. Genome Medicine. 2018; 10(82): 1-19.

[45] Ding YL, Fu J, Chen J, Mo SF, Xu S, Lin N, Qin P, McGrath_E. Molecular characterization and antimicrobial susceptibility of Staphylococcus aureus isolated from children with acute otitis media in Liuzhou, China. BioMed Central Pediatrics. 2018; 18: 388-393.

[46] Harastani HH, Araj GF, Tokajian ST. Molecular characteristics of Staphylococcus aureus isolated from a major hospital in Lebanon. International Journal of Infectious Diseases. 2014; 19: 33-38.

[47] Oliveira DC, de Lencastre H. Multiplex PCR strategy for rapid identification of structural types and variants of the mec element in methicillin-resistant Staphylococcus aureus. Antimicrobial Agents and Chemotherapy. 2002; 46(7): 2155-2161.

[48] Robinson DA, Enright, MC. Evolutionary models of the emergence of methicillin-resistant Staphylococcus aureus. Antimicrobial Agents Chemotherapy. 2003; 47(12): 3926-3934.

[49] DeLeo FR, Kennedya AD, Chenb L, Wardenburgc JB, Kobayashia SD, Mathemab B, Braughtona KR, Whitneya AR, Villaruzd AE, Martense CA, Porcellae SF, McGavinf MJ, Ottod M, Musserg JM, Kreiswirth BN. Molecular differentiation of historic phage-type 80/81 and contemporary epidemic Staphylococcus aureus. Proceedings of the National Academy of Sciences of the United States of America (PNAS). 2011; 1-6.

[50] Suhaili Z, Noor S, Mohamad M, Abdul R, Rachman A, Desa NM, Yeo CC. Draft genome sequence of Staphylococcus aureus KT/312045, an ST1-MSSA PVL positive isolated from pus sample in East Coast Malaysia. Genomics Data. 2016; 9: 111-112.

[51] David MZ, Boyle-VavraS,Zychowski DL, Daum RS. Methicillin-Susceptible Staphylococcus aureus as a Predominantly Healthcare-Associated Pathogen: A Possible Reversal of Roles? PLoS One. 2011; 6(4): 1-8.

[52] Monecke S, Baier V, Coombs GW, Slickers P, Ziegler A, Ehricht R. Genome sequencing and molecular characterization of Staphylococcus aureus ST772-MRSA-V, "Bengal Bay Clone”. BioMed Central Research Notes. 2013; 6(548): 1-7.

[53] Brennan GI, Shore AC, Corcoran S, Tecklenborg S, Coleman DC, O'Connell B. Emergence of hospital- and community-associated Panton-Valentine leukocidin-positive methicillin-resistant Staphylococcus aureus genotype ST772-MRSA-V in Ireland and detailed investigation of an ST772-MRSA-V cluster in a neonatal intensive care unit. Journal of Clinical Microbiology. 2012; 50(3): 841-847.

[54] Monecke S, Skakni L, Hasan R, Ruppelt A, Ghazal SS, Hakawi A, Slickers P, Ehricht R. Characterization of MRSA strains isolated from patients in a hospital in Riyadh, Kingdom of Saudi Arabia. BioMed Central Microbiology. 2012; 12 (1): 146-510.

[55] Pokhrel RH, Aung MS, Thapa B, Chaudhary R, Mishra SK, Kawaguchiya M, Urushibara N, Kobayashi, N. Detection of ST772 Panton-Valentine leukocidin-positive methicillin-resistant Staphylococcus aureus (Bengal Bay clone) 
and ST22 S. aureus isolates with a genetic variant of elastin binding protein in Nepal. New Microbes and New Infection. 2016; 11: 20-27.

[56] Sanchini A, Del Grosso M, Villa L, Ammendolia MG, Superti F, Monaco M, Pantosti A. Typing of Panton-Valentine leukocidin-encoding phages carried by methicillin-susceptible and methicillin-resistant Staphylococcus aureus from Italy. Clinical Microbiology and Infection. 2014; 20(11): 840-846.

[57] Williamson DA, Roberts SA, Ritchie SR, Coombs GW, Fraser JD, Heffernan H. Clinical and molecular epidemiology of methicillin-resistant Staphylococcus aureus in New Zealand: rapid emergence of sequence type 5 (ST5)SCCmec IV as the dominant community-associated MRSA clone. PLoS One. 2013; 8(4): 1-7.

[58] Boswihi SS, Udo EE, Al-Sweih N. Shifts in the Clonal Distribution of Methicillin Resistant Staphylococcus aureus in Kuwait Hospitals: 1992-2010. PLoS One. 2016; 11(9): 1-21.

[59] Neela V, Ehsanollah GR, Zamberi S, Van Belkum A, Mariana NS. Prevalence of Panton-Valentine leukocidin genes among carriage and invasive Staphylococcus aureus isolates in Malaysia. International Journal of Infectious Diseases. 2009; 13(3): e131-e132.

[60] Ellington MJ, Ganner M, Warner M, Cookson BD, Kearns AM. Polyclonal multiply antibiotic-resistant methicillinresistant Staphylococcus aureus with Panton-Valentine leucocidin in England. Journal of Antimicrobial Chemotherapy. 2010; 65(1): 46-50.

[61] Raji A, Ojemhen O, Umejiburu U, Ogunleye A, Blanc DS, Basset, P. High genetic diversity of Staphylococcus aureus in a tertiary care hospital in Southwest Nigeria. Diagnostic Microbiology and Infectious Disease. 2013; 77(4): 367369.

[62] D'Souza N, Rodrigues C, Mehta A. Molecular characterization of methicillin-resistant Staphylococcus aureus with emergence of epidemic clones of sequence type (ST) 22 and ST 772 in Mumbai, India. Journal of Clinical Microbiology. 2010; 48(5): 1806-1811.

[63] Shambat S, Nadig S, Prabhakara S, Bes M, Etienne J, Arakere, G. Clonal complexes and virulence factors of Staphylococcus aureus from several cities in India. BioMed Central Microbiology. 2012; 12(64): 1-9.

[64] Blomfeldt A, Larssen KW, Moghen A, Haugum K, Steen TW, Jorgensen SB, Aamot HV. Bengal Bay clone ST772MRSA-V outbreak: conserved clone causes investigation challenges. Journal of Hospital Infection. 2017; 95(3): 253-258.

[65] Okorie-Kanu OJ, Anyanwu MU, Ezenduka EV, Mgbeahuruike AC, Thapaliya D, Gerbig G, Ugwuijem EE, OkorieKanu CO, Agbowo P, Olorunleke S, Nwanta JA, Chah KF, Smith TC. Molecular epidemiology, genetic diversity and antimicrobial resistance of Staphylococcus aureus isolated from chicken and pig carcasses, and carcass handlers. PLoS One. 2020; 14: 15(5): e0232913.

[66] Jaton L, Pillonel T, Jaton K, Dory E, Prod'hom G, Blanc DS, Tissot F, Bodenmann P, Greub G. Common skin infection due to PantoneValentine leucocidin-producing Staphylococcus aureus strains in asylum seekers from Eritrea: a genome-based investigation of a suspected outbreak. Clinical Microbiology and Infection. 2016; 22(8): 1-4. 